\title{
The Monegros-type chert: Petrographic characterization and prehistoric use
}

\author{
Luis Miguel García-Simón ${ }^{1}$, Rafael Domingo ${ }^{2}$ \\ 1. Universidad de Zaragoza. Área de Prehistoria. Pza. Constitución, s/n. 22001 Huesca, Spain. \\ Email: luisgarciasimon@gmail.com \\ 2. Universidad de Zaragoza. Área de Prehistoria. C/ Pedro Cerbuna, 12. 50009 Zaragoza, Spain. \\ Email: rdomingo@unizar.es
}

\begin{abstract}
:
In recent years, allusions to exploitation of a so-called "Monegros-type" chert have been a commonplace in archaeological literature, mostly in Iberia but also in southern France. It has been also a routine that these references did not include a true petrographic characterization, being mere de visu descriptions of those products.

This work presents, for the first time, macro and microscopic characterizations of some of the most outstanding chert outcrops located in the Middle Ebro Basin. There, tertiary limestone sediments that form the top part of the flat plateau reliefs hold great quantities of chert nodules. The noteworthy erosive processes that have affected this area have facilitated the gathering of those cherts: they are easy to find either in their original location, still embedded in the limestone layers, or in secondary position along the enormous glacis that connect those flat reliefs to the river terraces. Two main flint varieties have been defined: Monegros and Evaporitic of Ebro. Both were originated in continental lacustrine environments. They are fine-grained and offer excellent knapping possibilities; hence its common use since prehistoric times to recent semi-industrial exploitations related to $18^{\text {th }}$ century gunflint productions.

This paper offers a preliminary study that will be developed in a forthcoming $\mathrm{PhD}$ dissertation, but we also include examples of its prehistoric exploitation in the Ebro Basin and abroad.
\end{abstract}

Keywords: Monegros-type chert; Evaporitic of Ebro-type chert; Ebro tabular chert; Iberian Peninsula; Prehistory

\section{Introduction}

The geographical name 'Monegros' has been traditionally used in Iberian and French Prehistoric literature to describe a high-quality, dark-coloured chert that presents Liesegang rings and bioclasts of charophyte algae, indicating its formation in a continental carbonated lacustrine environment. Frequently, their supposed outcrops have been located loosely in the middle Ebro Basin (Roy et al., 2013; in press; Vaquer \& Remicourt 2006; Vaquer \& Vergély 2006).

Published by the School of History, Classics and Archaeology, University of Edinburgh ISSN: 2055-0472. URL: http://journals.ed.ac.uk/lithicstudies/

This work is licensed under a Creative Commons Attribution 2.5 UK: Scotland License. 
Monegros is a vast natural region located in Aragón (Spain), in the heart of the middle Ebro Basin, which occupies part of the current provinces of Zaragoza and Huesca (Figure 1). In recent years massive irrigation works have partially transformed its landscape, but outside these cultivated spots it is still one of the most arid territories in the Iberian Peninsula. This feature makes it one of the most suggestive and attracting natural areas of SW Europe, rich in taxonomic peculiarities and a high index of endemic species. In Geological terms the name Monegros has been utilised to describe the evolution of the middle Ebro Basin, covering lithologies from the middle Eocene (Lutecian) to the upper Eocene (Turolian) (Quirantes 1978).

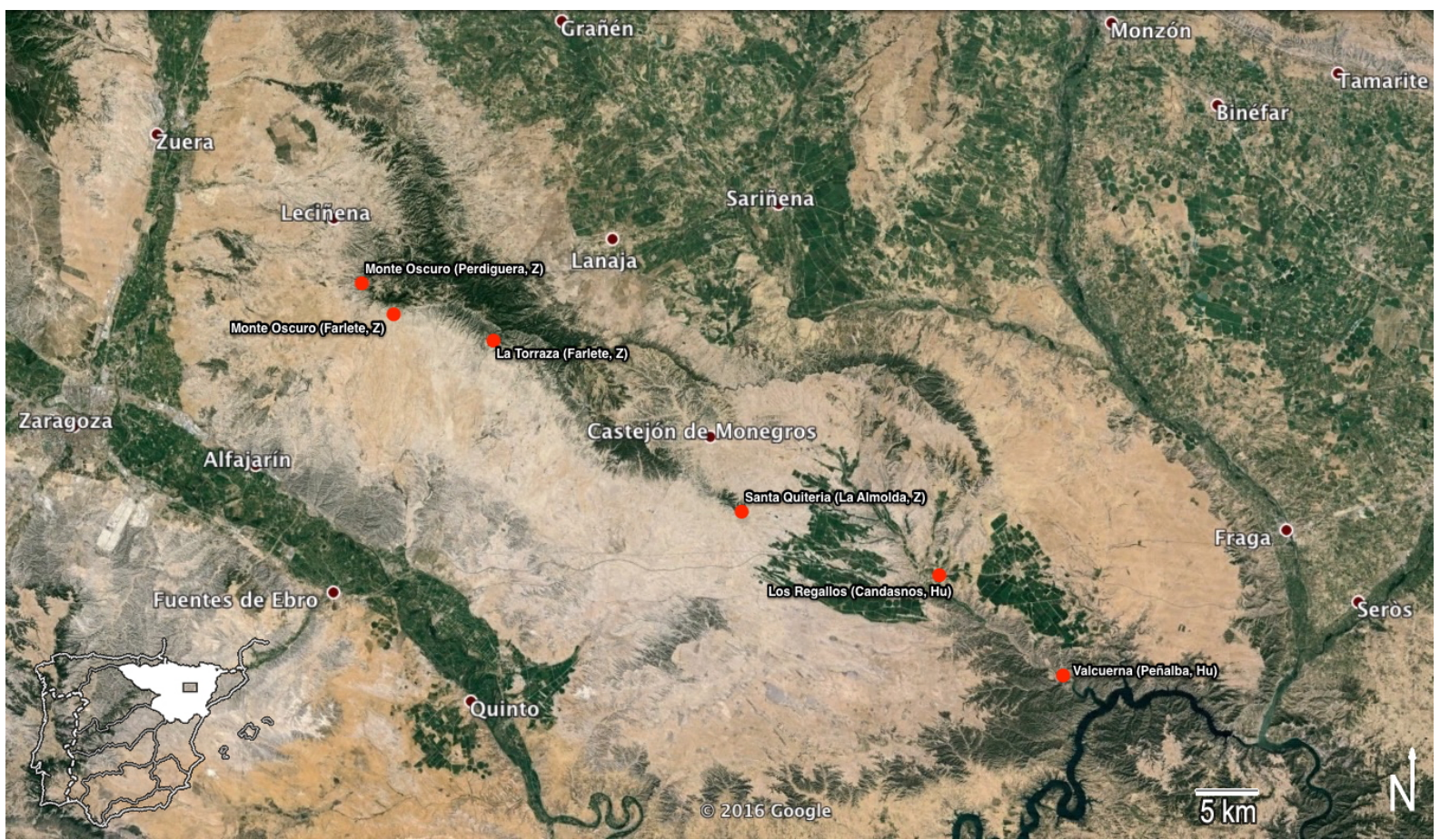

Figure 1. Chert outcrops of Monegros and Ebro Evaporitic types. (Image from Google Earth.)

We cannot confirm precisely when this name became popular among archaeologists, but meetings like that of the ISKM held at Barcelona in September 2015 (ISKM 2015) are a good example of its common employment. We think that this can be linked to the territorial and chronological implications derived from the Geology, as well as to the well-known abundance of siliceous outcrops easily accessible, exploited since ancient times up to the 20th century. Although a handy denomination, we must remember that most -if not all- of the studies that have used the term Monegros lack of a detailed analytical basis. The wide employment of this term to name all the cherts from the middle Ebro Basin has caused confusion due to the absence of a precise systematization, a situation to which we can also add the frequent use of other names as synonyms of Monegros chert, the most common being Botorrita chert. Botorrita is a small village, barely $20 \mathrm{~km}$ to the south of Zaragoza, where siliceous outcrops were massively exploited along the late 18th century to produce gunflints (Barandiarán 1974: 209). This name appears as recently as in 2013 in the publication of the nearby Mesolithic campsite of Cabezo de la Cruz (Leorza 2013).

Our main aim is to systematize the knowledge of the lithic raw materials available in the Ebro Basin: localisation, accessibility and petrographic features, in order to define the extant chert varieties and organise them into classified groups. 


\section{Methods}

\subsection{Geographic and geologic context}

The geological history of the Ebro Basin has been systematized after the stratigraphy documented in the Alcubierre Ranges, the highest elevation of the middle Depresion. Those Ranges structure the Monegros area, whose name (Monegros $=$ Montes Negros $=$ Black Mountains) derives from the traditional abundance of pines and kermes oaks. In geological terms, Monegros limits to the north with the PrePyrenean Ranges, to the east with the Catalan Coastal Ranges and to the west with the Bureba corridor that links the Ebro Basin to the Duero Basin and the Northern Plateau (Meseta). Its geological features are simple: from the Late Eocene (Upper Priabonian) to the Upper or Middle Miocene (Upper Vallesian or Turolian) the centre of the Basin was an endorreic system that received the waters of the rivers flowing from the surrounding Ranges. In the margins of the Basin, different systems of fluvial and alluvial fans deposited the current lithologies, while in the central area there were carbonated and evaporitic lakes. Those lakes were gradually displaced southwards when the Pyrenean rising (Alpine Orogeny) took place.

Between 12 and 8 million years ago there was an exoreic episode that caused the erosive removing of the Basin deposits to the Mediterranean and started the shaping of the presentday landscape, as a result of the activity of a growing fluvial network under semiarid climatic conditions. Nowadays several hydrological systems structure the territory and delimitate the Neogene geological formations. The Ebro River is the main watercourse; some of its most important tributaries are Gállego and Alcanadre (which is not a direct tributary) by the north and Jalón, Huerva, Martín, Guadalope and Matarraña by the south. They have modelled the Tertiary deposits and the Quaternary detrital formations that cover them.

The top part of the reliefs (Castellar, Alcubierre ranges, Monte Oscuro and Sigena north of the Ebro River and La Muela and La Plana to the south) is formed by structural calcareous plataforms (Fm. Alcubierre), where the siliceous nodules are nowadays embedded. Massive limestones alternate with levels of marls, silts and occasionally gypsums (Figure 2). The highest elevations barely surpass $800 \mathrm{~m}$ A.S.L.

Prior to the setting of carbonate lacustrine systems that led to the formation of the massive limestones, the centre of the Basin was occupied by several evaporitic lacustrine systems framed by others of carbonate character. The most important gypsum deposits, that also include some chert nodules, are part of the Fm. Zaragoza. Besides limestones and gypsums, marls, sandstones and conglomerates layers, and clay formations compose the Monegros lithology, although those deposits do not hold siliceous nodules.

In the last five years we have sampled 57 outcrops (42 primary and 15 secondary) in 26 different locations of the Monegros area, covering a narrow territory $80 \mathrm{~km}$ long limited to the calcareous strata where chert appears; we have defined their precise features and the varieties present in the geological record: more than 400 samples have been collected and classified into a lithotheque that includes information concerning their localisation and macro and microscopic analysis. The main data are included in digital editable files.

\subsection{Petrographic analysis}

Although offering limited information, macroscopic analysis provides important data about four basic parameters: cortex, siliceous mass, surface appearance, inclusions and fossils, and finally structures. Their description permits a preliminary basic classification based on their diagenetic environment and main features (Table 1). 


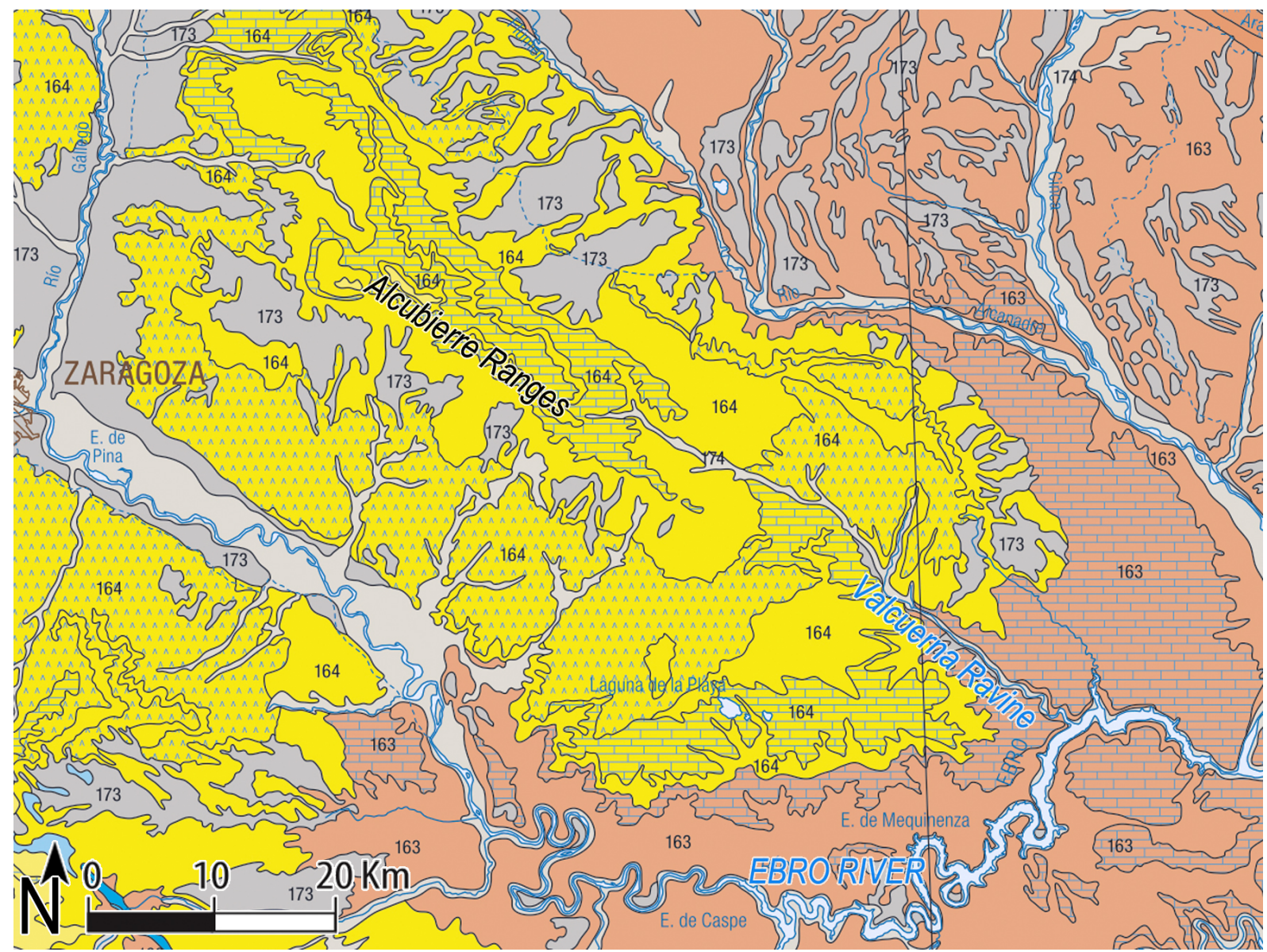

Figure 2. Geological map of Monegros area. Source: IGME. Geological formations: Quaternary. 174. Conglomerate, sandstone, gravel, sand, silt and clay; 173. Conglomerate, gravel, sand, lutite, marl, calcarenite, travertine limestone and toba. Miocene: 164. Conglomerate, sandstone, lutite, limestone, marl and gypsum; 163. Conglomerate, sandstone, lutite, limestone and gypsum.

Cortex is the boundary between the host rock and chert, and covers like a crust all the siliceous mass in contact with the rock where it was formed. Its mere macroscopic characterization can help to link the chert to a precise outcrop type (carbonated or evaporitic rocks, conglomerates, etc.). When describing the cortex, we must retain its thickness, union with the siliceous mass, rolling degree, lithology and the inclusions or fossils that could be observed. The description of its surface offers important conclusions regarding the postdepositional processes and possible transports from an original outcrop to a secondary position. Depending of its colour, we can deduce abundance of iron oxides (reddish colours), manganese or organic matter in anaerobic conditions (blackish cortex) (Mangado 2005: 36).

The siliceous mass features offer valuable information concerning the cherts' knappability. We will retain the grain measure (fine-medium-coarse), the surface ruggedness, texture after Dunham's classification for carbonate rocks (1962) (mudstone, wackestone, packstone and grainstone) and, finally, visible alterations: physical (fractures, fissures) or chemical (patina, new-crusts). Those parameters allow determining the chert knappability (excellent, good, medium, bad or very bad).

Colour is the most conspicuous external feature in a chert and offers information concerning its diagenesis: dark cherts could have been formed in reductive or anaerobic sedimentary environments, while reddish or yellowish cherts could respond to oxidative formations. Nevertheless, colour is retained as a subjective parameter, barely determinant to classify a variety. Particular elements such as the coloration distribution (striped, solid, etc.), the transparency index and the presence of patina are included. 
Table 1. Macroscopic and microscopic features of the analysed varieties.

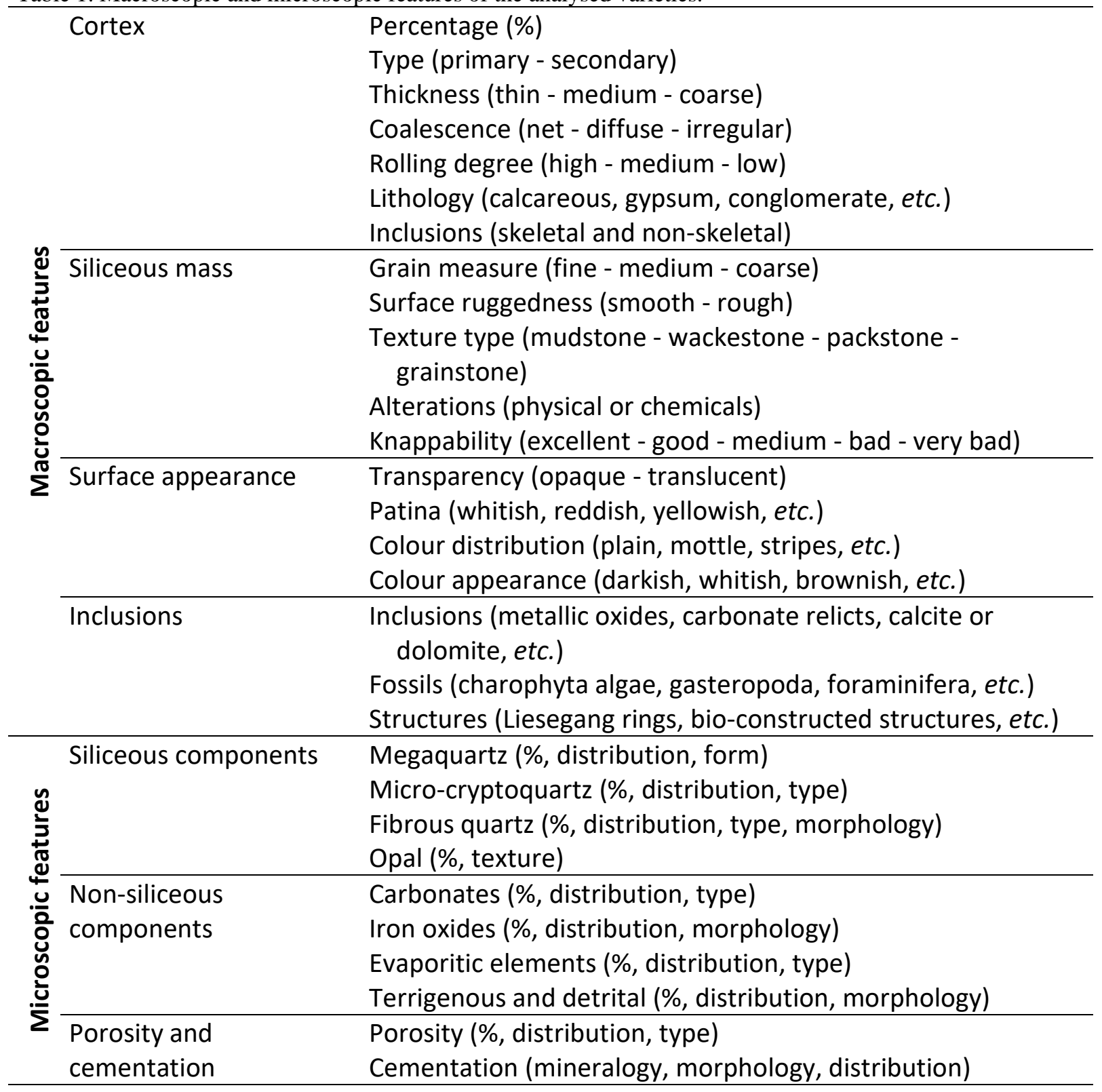

Siliceous mass can integrate two types of components depending on their origin: skeletal and non-skeletal. Those last, always in lesser proportions than opals and quartzs, may help to characterize chert varieties. The most common non-skeletal components (impurities) are metallic oxides, carbonate relicts, lenticular gypsum pseudomorphs, etc. Fossils can offer information concerning the formation environment or the diagenesis, due to the relevance of palaeontology as a chronological marker for some periods. Sadly, chert formation processes do not favour their conservation, appearing most of them highly deformed; most common fossils in our study area are gastropoda, stems and oogonia of charophyta algae, porifera spicules and foraminifera.

Besides fossils and impurities, we can determine the existence of sedimentary or bioconstructed structures. Most common sedimentary structures in Monegros cherts are Liesegang rings: although common, they do not appear systematically.

Twenty-five samples of the studied outcrops were selected for thin sections, in order to establish at the microscope their mineral components and their interactions, that is to say, their textures. These quantitative and qualitative parameters are less subjective than the mere 
macroscopic description, but we cannot forget that this is a destructive technique. For this petrographic description we retained the presence and percentage of siliceous components namely megaquartz, cryptoquartz, fibrous quartz and opal-, as well as siliceous microfossils like porifera spicules. We have taken into account non-siliceous components like carbonates, iron oxides, evaporitic minerals like gypsum and terrigenous or detrital elements like silt minerals. Last, we detailed the presence of porosities and the possible extant cements.

In the present state of our research we have not applied physical or chemical analytics, mainly by economic and temporal reasons. Nevertheless, in a forthcoming future we envisage to employ X-Ray Diffraction (XRD) to obtain the mineralogical composition, X-Ray Fluorescence (XRF) for the chemical composition and perhaps the analytic that is currently giving better results: Inductively Coupled Plasma Mass Spectometry with Laser Ablation (LA-ICP-MS), that offers high-sensitive chemical composition data.

\section{Results}

The main area of siliceous outcrops in NE Iberia, known and exploited since prehistoric times (Tilo 1991), is the central-eastern part of the Ebro Basin, and chiefly the Monegros region. As previously said, the Alcubierre Ranges, a Neogene platform composed by limestones, marls and gypsums, is one of the most chert-proliferous environments in this region. We will detail now some of the most conspicuous locations.

\subsection{Los Regallos (Candasnos, Huesca)}

It is a ravine that flows at the feet of Tozal de Los Regallos, where an Early Iron Age (8th century BCE) settlement was established. The bottom filling holds copious cherts of different origins in secondary position (Figure 3a-3b).

Recovered samples appear as sub-angular nodules that frequently lack of cortex due to postdepositional processes. Two types can be differentiated de visu:

The first one has medium or fine grain, smooth surface and wackestone texture. It has no physical alterations, although some samples present patina due to weathering. Its knappability is good. It includes iron oxides, possible micrite and inertite and relicts of the original carbonate. Oogonia and stems of charophyte algae form its fossil content; hence, we can determine its formation in a sedimentary environment (carbonated lacustrine continental). Two sub-varieties can be documented: the first one barely presents charophyte bioclasts but includes many carbonate relicts; it has no Liesegang rings and its colour is brownish (probably due to the high carbonate content). In the other one the carbonates are easily seen; it has darkish colours, and Liesegang rings are frequent.

The second type appears in smaller sizes and is usually covered by cortex despite the visible rolling damages. This is a fine-grained chert, with smooth or rough surface and mudstone texture. Occasional crusts appear on its surface, although its knapping quality remains good. Hematite granules, occasionally massive, are its only inclusions. It is an azoic chert whose formation environment was evaporitic lacustrine continental. A thin section of one sample of this variety was analysed (Figure 4a): the presence of length-slow chalcedony confirmed its environmental diagenesis in an evaporitic system. 

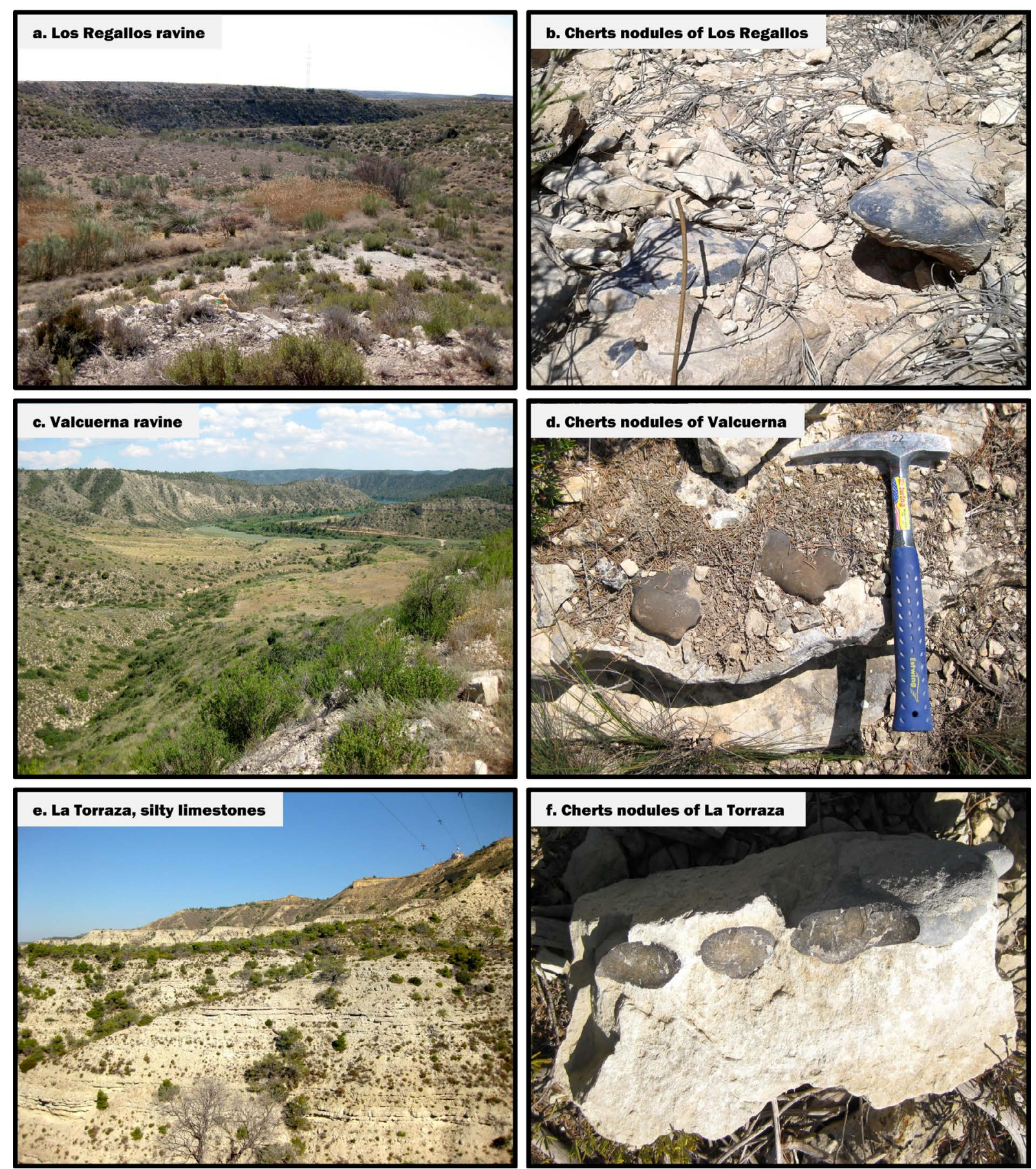

Figure 3. General view of outcrops and chert nodules: a, b Los Regallos; c, d Valcuerna; e, f La Torraza.

\subsection{Valcuerna (Peñalba, Huesca)}

Valcuerna is a long ravine that links the eastern footsteps of the Alcubierre Ranges to the Ebro River watercourse and that is a clear passageway to access different territories. The calcareous steps that frame it hold massive quantities of isolated chert nodules and siliceous layers embedded in the matrix where they were originated (Figure 3c-3d). Erosive processes set them loose from the limestone levels; they are abundant and easily accessible in the bottom of the flat-floor valleys (locally known as vales).

We have sampled 15 different outcrops, ten in primary and five in secondary positions. We have been able to distinguish 20 siliceous varieties of the Monegros-type chert. All of them belong to a carbonate continental lacustrine environment. They usually appear as 
nodules, although in some instances they are stratified. Those cherts have thin calcareous cortex, they are fine-grained and their surface is smooth, with an excellent knappability. They are opaque or translucent, of wackestone-type texture and present inclusions of metallic oxides, possible inertite and carbonate relicts. There are frequent and copious presence of bioclasts: charophyte algae and lacustrine gasteropods. Liesegang rings appear in some of the samples. As complementary information, we retained de visu the most frequent colours: greyish and darkish.
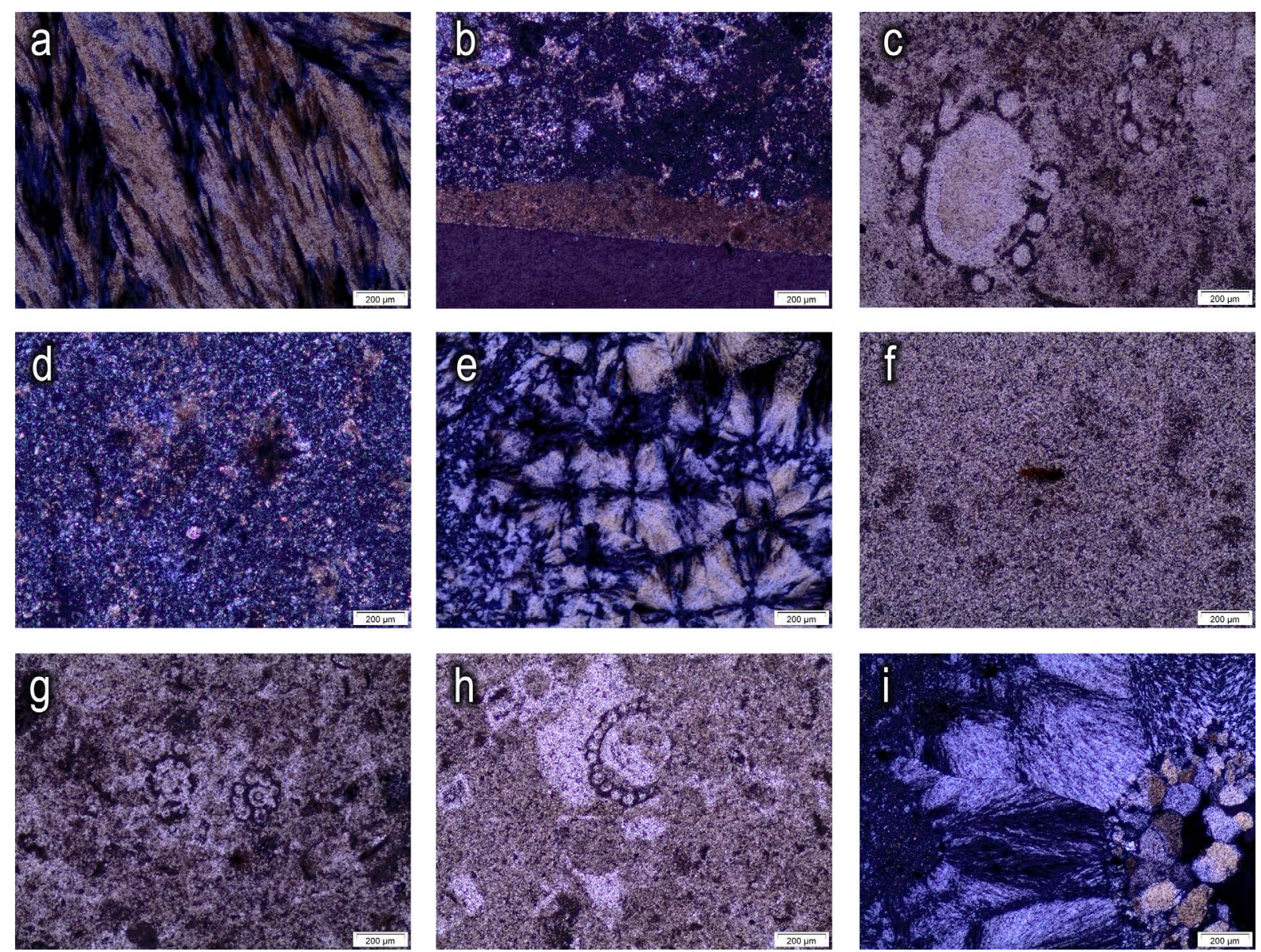

Figure 4. Microscopic details. a. Fibrous quartz (quartzine-lutecite), Los Regallos (type 2). b. Cortex union with the siliceous mass, Valcuerna (type 1). c. Stem of charophyta section, Valcuerna (type 2). d. Carbonate relict, La Torraza. e. Spherulite of fibrous quartz, Monte Oscuro (type 1). f. Siliceous mass and iron oxides, Monte Oscuro (type 2). g., h. Stem of charophyta section and carbonated relict, Santa Quiteria (types 1 and 2). i. Fibrous quartz (chalcedonite) and macroquartz, Santa Quiteria (type 3).

Nevertheless, their lithological variability allows us to separate them in two main groups that can appear both in primary or secondary positions with the same features. On the one hand, nodular cherts, with homogeneous siliceous mass and excellent knappability; on the other, stratified cherts, whose quality is worst because of the highest presence of relicts of the original carbonate, with numerous geodes and hollows that can even cause natural fissures. Their main colours are brownish and their silicification process is still uncompleted.

Nine of the samples have been analysed at the microscope (Figure $4 \mathrm{~b}$ and $6 \mathrm{c}$ ): they are composed by $60-80 \%$ micro-cryptoquartz in saccharoidal mosaic, and by $10-20 \%$ chalcedonite (negative elongation) associated to the filling of bioclastic porosities, of spherulitic and botryoidal conformation. Micrite carbonates are frequent, sometimes in replacement process. Anecdotally, some thin sections show Liesegang rings (Figure 5a), 
calcite or dolomite rhombohedrals, macroquartz crystals and, punctually, opal. These two last features are linked to stratified outcrops samples and limited knapping capacity.

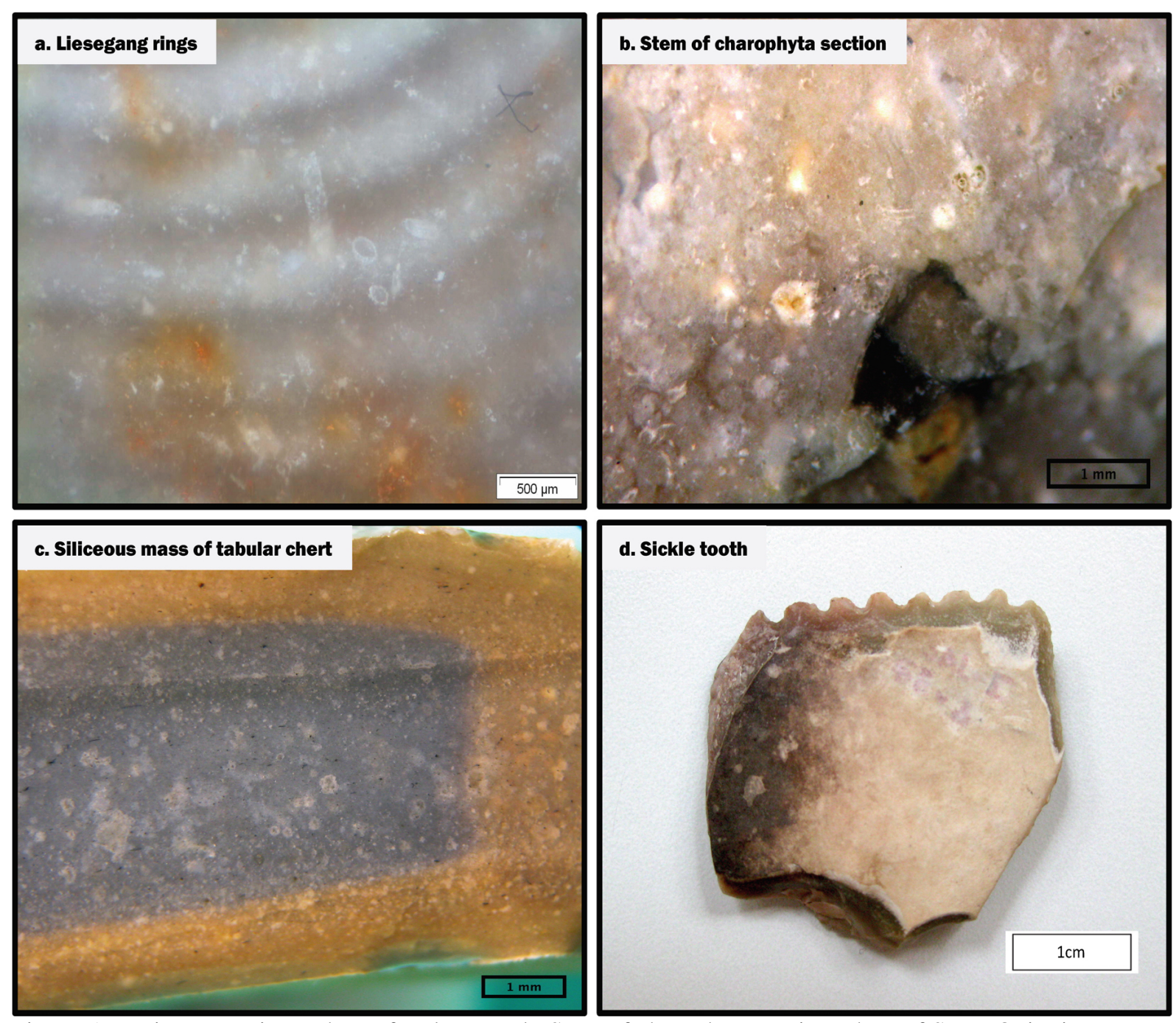

Figure 5. a. Liesegang rings, chert of Valcuerna; b. Stem of charophyta section, chert of Santa Quiteria; c. Mass siliceous of tabular chert detail, chert of Monte Oscuro; d. Sample of sickle tooth of tabular chert, Carrasca cave (Almazorre, Huesca).

\subsection{La Torraza (Farlete, Zaragoza)}

Cherts appear embedded in the silty limestones that form the San Caprasio hill next to the village of Farlete (Figure 3e-3f). They have thin calcareous cortex, medium grain and smooth surface; their knappability is medium. Their texture can be defined as wackestone, with abundant carbonate relicts, chiefly stem fragments and oogonia of charophyta algae, which are indicative of their formation in a carbonated continental lacustrine environment. The thin section (Figure 4d) shows a high index of carbonate (40-50\%), microcryptocrystaline silica (40-50\%) and length-fast chalcedony (>3\%), associated to the filling of some bioclasts and numerous hollows that affect all of it. They have some calcite or dolomite rhombohedrals. The silicification process of the limestone is still unfinished, but its quartz content is enough for knapping. 


\subsection{Santa Quiteria (La Almolda, Zaragoza)}

The top part of the calcareous relief where nowadays stands the hermitage of Santa Quiteria holds some siliceous outcrops: three of them have been selected for analysis.

A first variety is formed by chert nodules of calcareous cortex, fine-medium grain and smooth-rough surface, well suited for knapping. They have wackestone texture and present inclusions of metallic oxides, possible inertite and original carbonate relicts, as well as abundant bioclasts of charophyta algae (Figure 5b). At the microscope they are mainly composed by micro-cryptocrystaline quartz (80\%), with frequent presence of calcedonite (10\%) (spherulytical and botryoidal), associated to the filling of porosities. Significantly, metallic oxides tend to be concentrated next to cortical areas.

The second variety is de visu very similar to the former one. Nevertheless, at the microscope the micro-cryptocrystaline quartz is far less frequent $(50 \%)$, there is a higher presence of length-fast chalcedony $(<20 \%)$ and original carbonate $( \pm 30 \%)$. This, added to a higher porosity, shows that this is a carbonate rock still undergoing a silicification process.

The third chert formations appear stratified, in strata of centimetre thickness and metric extension, and present calcareous or marly cortex, fine-medium grain and smooth-rough surface; their suitability for knapping is heavily conditioned by its many hollows, partially or fully filled by macroquartz crystals. The wackestone texture, it has frequent metallic oxides are responsible of its brownish colour, and bioclasts of charophyta algae. Under the microscope it is very similar to the nodular variety (micro-cryptocrystaline quartz: 60-70\%), except for a higher presence of metallic oxides and chalcedonite (20\%) as first-generation cement and macroquartz (2\%) as second-generation cement in the pore-filling.

All lithologies of Santa Quiteria outcrops were formed in a carbonated continental lacustrine environment (Figure 6a-5b; Figure 4g-6h-6i).

\subsection{Monte Oscuro (Perdiguera-Farlete, Zaragoza)}

We have carefully prospected the south and west slopes of Monte Oscuro, in the Alcubierre Ranges (Figure 6c-5d). There, the vegetal cover is less dense and slope deposits are more developed. We have documented and sampled ten different chert outcrops, where we have recognized two siliceous varieties that belong to the Ebro Evaporitic type.

First, there is a chert with an irregular gypsum cortex, medium or fine grain, smooth or rough surface and occasional presence of geodes that influence the knapping suitability. It is an opaque or translucent or totally translucent chert, of mudstone texture, with no inclusions excepting some possible micrite relicts, metallic oxides and lenticular gypsum pseudomorphs without any evidence of skeletal components.

At the microscope (Figure 4e) its main component is length-slow chalcedony. There are fibrous quartz as first-generation cement in the hollow filling, and macroquartz and secondgeneration crystalline quartz completing those fillings. There is a high quantity of the original carbonate, sometimes in a striped disposition, which allows characterizing de visu these cherts for their external aspect and gives them their light brownish colour. There is a discrete presence of gypsum lenticular pseudomorphs and ferric oxides, some of the profited by the chalcedony fibres as a core.

On the other hand, there is a chert with an extra-thin cortex, of orange colour and silicified when observed at the microscope. The siliceous mass presents fine grain, smooth surface and no alterations at all: it is a high-quality raw material. It is opaque or translucent, has wackestone-type texture and presents inclusions of inertite and occasional metallic oxides. Thin sections (Figure 4f) are almost exclusively composed of micro-cryptocrystalline silica, with some micrite relicts and oxides, the last ones more frequent next to the cortex, where we can find also the sole carbonate relicts identified, that can be occasionally abundant. 

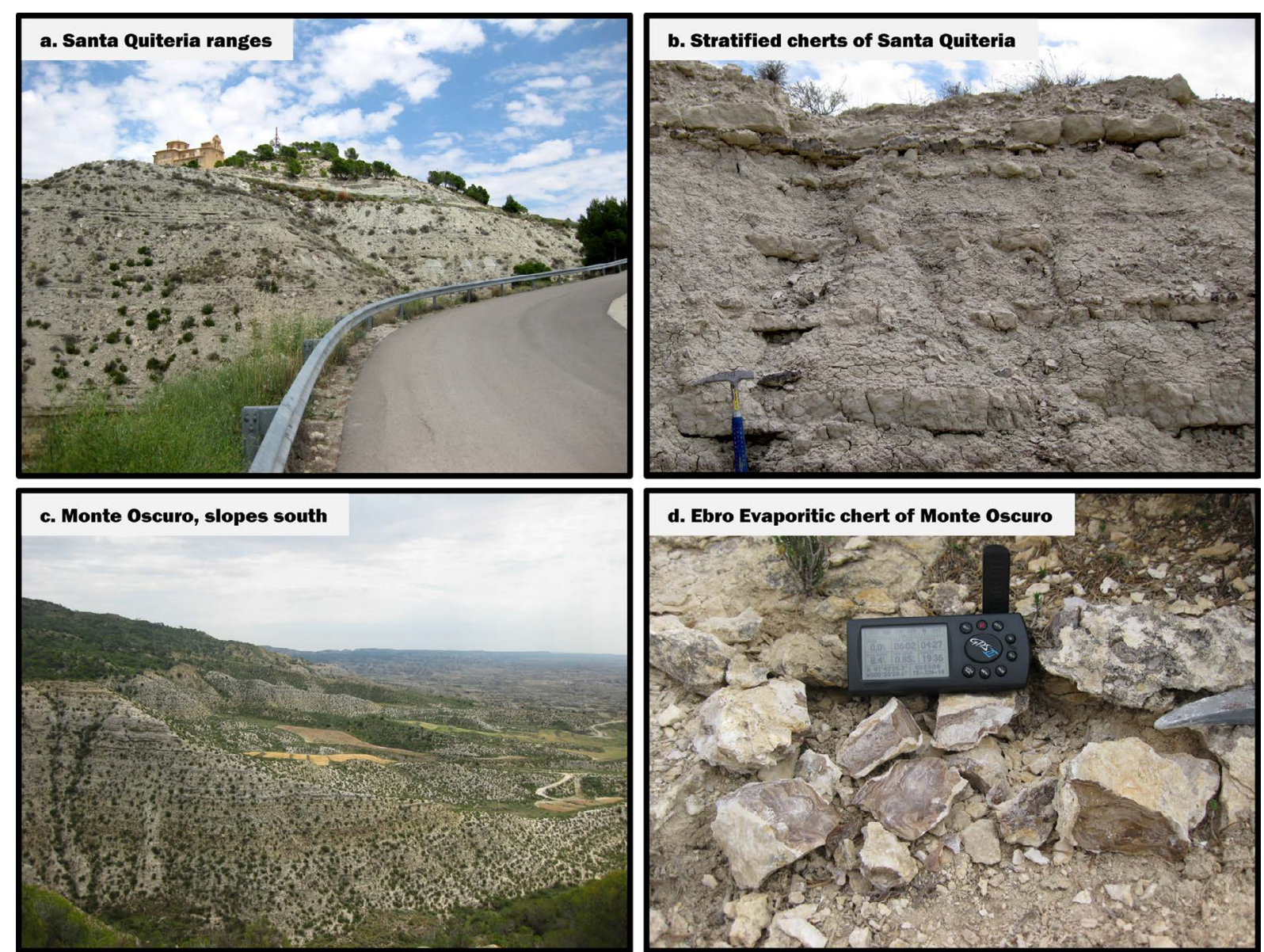

Figure 6. General view of the outcrops and chert nodules: a, b Santa Quiteria; c, d Monte Oscuro.

In this siliceous typology there is a striking absence of bioclasts as well as of other macro- or microscopic components that allow us to ascribe it to a precise sedimentary environment. Its apparition next to other fully evaporitic lithologies such as gypsums, or the presence of some cherts embedded in those gypsums, makes us propose its formation in that type of environments, in the expectation of forthcoming analytics that could confirm this attribution. Its main feature is a tabular morphology (Figure 5c): small tablets of centimetric width and length, but millimetric thickness, with silicified cortex that do not hamper its knapping (not surprisingly, this variety was widely employed for knapping sickle lithic elements that appear in many sites across the Ebro Basin: see discussion for further references). Although usually the tabular cherts are flat, sometimes they appear in irregular shapes, which can make difficult its correct profit for knapping purposes.

\section{Discussion and conclusions}

The main aim of the characterization of some of the most conspicuous chert outcrops (Table 2) in the Central area of the Ebro Basin is obtaining a deeper knowledge of the raw material management by the prehistoric groups that frequented this territory and the neighbouring regions. As seen in the detailed descriptions of the surveyed outcrops, we must distinguish two main categories that are related to the sedimentary environment where those rocks were formed.

On the one hand, we have the carbonated continental lacustrine lithologies, well suited for knapping, with charophyte algae bioclasts and occasional Liesegang rings. We propose for them the term 'Monegros chert', widely employed in the extant historiography. 


\begin{tabular}{|c|c|c|c|c|c|}
\hline & \multicolumn{2}{|c|}{ LOS REGALLOS } & \multicolumn{2}{|c|}{ VALCUERNA } & \multirow[t]{2}{*}{ LA TORRAZA } \\
\hline & Type 1 & Type 2 & Type 1 & Type 2 & \\
\hline Environment formation & carbonated & evaporitic & carbonated & carbonated & carbonated \\
\hline Position & secondary & secondary & primary and secondary & primary and secondary & primary \\
\hline Morphology & nodules & nodules & nodules & stratified & nodules \\
\hline Host rock & limestone & gypsum & limestone & limestone & silty limestone \\
\hline Cortex thickness & thin & thin & thin & thin & thin \\
\hline Grain measure & medium or fine & fine & fine & fine & medium \\
\hline Surface ruggedness & smooth & smooth or rough & smooth & smooth & smooth \\
\hline Texture type & wackestone & mudstone & wackestone & wackestone & wackestone \\
\hline Alterations & patina & patina, concretions & - & fissures, geodes & - \\
\hline Knappability & good & good & excellent & medium & medium \\
\hline Colour appearance & brownish or darkish & whitish & greyish or darkish & brownish & greyish \\
\hline Inclusions & $\begin{array}{l}\text { iron oxides, } \\
\text { carbonates }\end{array}$ & hematite & iron oxides, carbonates & iron oxides, carbonates & $\begin{array}{l}\text { iron oxides, } \\
\text { carbonates }\end{array}$ \\
\hline Fossils & charophyta & - & charophyta, gasteropoda & charophyta, gasteropoda & charophyta \\
\hline Structures & Liesegang rings & - & Liesegang rings & - & - \\
\hline Siliceous components & - & $\begin{array}{l}\text { cryptoquartz }(45 \%) \text {, } \\
\text { fibrous quartz } \\
(45 \%)\end{array}$ & $\begin{array}{l}\text { cryptoquartz (80\%), } \\
\text { fibrous quartz (8\%) }\end{array}$ & $\begin{array}{l}\text { cryptoquartz }(60 \%), \\
\text { fibrous quartz }(15 \%)\end{array}$ & $\begin{array}{l}\text { cryptoquartz } \\
(45 \%), \text { fibrous } \\
\text { quartz (5\%) }\end{array}$ \\
\hline $\begin{array}{l}\text { Non-siliceous } \\
\text { components }\end{array}$ & - & $\begin{array}{l}\text { iron oxides }(6 \%) \text {, } \\
\text { carbonates }(4 \%)\end{array}$ & $\begin{array}{l}\text { iron oxides }(5 \%) \text {, } \\
\text { carbonates }(5 \%) \text {, other } \\
(2 \%)\end{array}$ & $\begin{array}{l}\text { iron oxides }(5 \%) \text {, } \\
\text { carbonates }(15 \%) \text {, other } \\
(2 \%)\end{array}$ & $\begin{array}{l}\text { iron oxides } \\
(1 \%), \\
\text { carbonates } \\
(45 \%), \text { other } \\
(2 \%)\end{array}$ \\
\hline Porosity & - & - & - & porosity (3\%) & porosity (2\%) \\
\hline
\end{tabular}




\begin{tabular}{|c|c|c|c|c|c|}
\hline & \multicolumn{3}{|c|}{ SANTA QUITERIA } & \multicolumn{2}{|c|}{ MONTE OSCURO } \\
\hline Environment formation & $\begin{array}{l}\text { Type } 1 \\
\text { carbonated }\end{array}$ & $\begin{array}{l}\text { Type } 2 \\
\text { carbonated }\end{array}$ & $\begin{array}{l}\text { Type } 3 \\
\text { carbonated }\end{array}$ & $\begin{array}{l}\text { Type } 1 \\
\text { evaporitic }\end{array}$ & $\begin{array}{l}\text { Type } \mathbf{2} \\
\text { possible evaporitic }\end{array}$ \\
\hline Position & primary & primary & primary & primary and secondary & primary and secondary \\
\hline Morphology & nodules & nodules & stratified & irregular nodules & tabular \\
\hline Host rock & limestone & limestone & limestone & gypsum & gypsum? \\
\hline Cortex thickness & thin & thin & thin & medium or thin & extra-thin \\
\hline Grain measure & medium or fine & medium or fine & medium or fine & medium or fine & fine \\
\hline Surface ruggedness & smooth or rough & smooth or rough & smooth or rough & smooth or rough & smooth \\
\hline Texture type & wackestone & wackestone & wackestone & mudstone & wackestone \\
\hline Alterations & - & - & fissures, geodes & geodes & - \\
\hline Knappability & good & medium & medium & medium or good & high-quality \\
\hline Colour appearance & darkish & darkish & brownish & brownish or whitish & greyish \\
\hline Inclusions & $\begin{array}{l}\text { iron oxides, } \\
\text { carbonates }\end{array}$ & $\begin{array}{l}\text { iron oxides, } \\
\text { carbonates }\end{array}$ & $\begin{array}{l}\text { iron oxides, } \\
\text { carbonates }\end{array}$ & $\begin{array}{l}\text { hematites, lenticular } \\
\text { gypsum pseudomorphs }\end{array}$ & $\begin{array}{l}\text { iron oxides, possible } \\
\text { inertite }\end{array}$ \\
\hline Fossils & charophyta & charophyta & charophyta & - & - \\
\hline Structures & - & - & - & striped sedimentation & - \\
\hline Siliceous components & $\begin{array}{l}\text { cryptoquartz } \\
(80 \%), \text { fibrous } \\
\text { quartz }(10 \%)\end{array}$ & $\begin{array}{l}\text { cryptoquartz } \\
(50 \%), \text { fibrous } \\
\text { quartz }(20 \%)\end{array}$ & $\begin{array}{l}\text { cryptoquartz } \\
(60 \%), \text { fibrous } \\
\text { quartz }(20 \%)\end{array}$ & $\begin{array}{l}\text { cryptoquartz (20\%), } \\
\text { fibrous quartz }(60 \%)\end{array}$ & $\begin{array}{l}\text { cryptoquartz (90\%), } \\
\text { fibrous quartz (3\%) }\end{array}$ \\
\hline $\begin{array}{l}\text { Non-siliceous } \\
\text { components }\end{array}$ & $\begin{array}{l}\text { iron oxides }(3 \%) \text {, } \\
\text { carbonates }(4 \%) \text {, } \\
\text { other }(2 \%)\end{array}$ & $\begin{array}{l}\text { iron oxides }(1 \%) \text {, } \\
\text { carbonates }(25 \%) \text {, } \\
\text { other }(1 \%)\end{array}$ & $\begin{array}{l}\text { iron oxides }(6 \%) \text {, } \\
\text { carbonates }(8 \%) \text {, } \\
\text { other }(2 \%)\end{array}$ & $\begin{array}{l}\text { iron oxides }(2 \%), \\
\text { carbonates }(15 \%), \text { other } \\
(1 \%)\end{array}$ & $\begin{array}{l}\text { iron oxides }(3 \%) \text {, } \\
\text { possible inertite }(3 \%) \text {, } \\
\text { other }(1 \%)\end{array}$ \\
\hline Porosity & porosity (1\%) & porosity (3\%) & porosity $(4 \%)$ & porosity $(2 \%)$ & - \\
\hline
\end{tabular}


On the other hand, the 'Ebro Evaporitic cherts' are azoic rocks, predominantly quartzines and lutecites or fibrous quartz of positive elongation, with gypsum pseudomorphs. Some samples are especially tenacious, which can be an advantage in some knapping techniques such as the pressure retouch employed for the double bevelled geometric microliths that become common in the Ancient Neolithic of the Ebro Basin. Interestingly, in many sites there is a clear shift in the selection of raw materials in favour of the Ebro Evaporitic whitish variety (for example, in the Arba de Biel sites (Montes et al. 2016; García-Simón et al. 2016), or in the Álava-Treviño area (Tarriño 2001; 2005).

The massive number of siliceous outcrops, their easy availability, and the overall good quality of both types of cherts make this region one of the most interesting of Iberia for the study of the lithic raw materials prehistoric supply. Perhaps the paradigm could be the Valcuerna ravine, where enormous quantities of chert can be found not only in its primary layers but also in secondary position, scattered on its flat bottom.

Our own on-going research, focused on the lithic materials management in prehistoric sites of the Ebro Basin, is confirming the wide employment of the Monegros and the Ebro Evaporitic varieties even in relatively remote locations where locally available chert outcrops might have been scarce or bad suited for the prehistoric groups purposes. Although we cannot discard previous employments nowadays poorly documented due to the limited findings from the most ancient Prehistoric periods, we can place the exploitation of the Monegros cherts at least in the Upper Palaeolithic, when it became common across the Basin. Roy et al. (2013) analysed some outcrops in the easternmost area of the Monegros territory when they studied the lithic supplies of Cova Gran's level 497C (Early Upper Palaeolithic). The authors distinguish two varieties after their colour: black and blue, although they recognize the necessity of further and more in-depth studies to fully understand its distribution. The Monegros outcrops they sampled were considered exogenous, being more than $80 \mathrm{~km}$ away from the analysed site. Finally, they mention the difficulties in distinguishing some of the Serra Llarga cherts from the Monegros type, as they share some basic features such as the charophyte presence and the Liesegang rings. According to Utrilla \& Montes (2007), in Magdalenian times Monegros chert was frequently employed in some of the sites from the Ebro Basin, although they only offer a de visu criterion: the presence of Liesegang rings (a feature that they visually describe as xyloid aspect). Also for Magdalenian times, Monegros cherts have been cited in Gazel (southern France) (Langlais \& Sacchi, 2006).

But most of the quotes on Monegros chert circulations are from postpalaeolithic occupations, in both sides of the Pyrenees. Utrilla et al. (2005) mention the existence of openair sites next to the outcrops near the Monegros endorreic lakes (not far from the Valcuerna ravine). They are very difficult to characterize in terms of chronocultural adscription because their poor conservation and the frequent reoccupations and reutilizations of this type of "quarry facies" sites, although some of the instruments could be clearly ascribed to the Notches and Denticulates Mesolithic. Some of the long blades that appear from the Middle Neolithic onwards in French and Spanish sites were knapped on Monegros chert: according to Perrin et al. (2006) they arrived to distant locations as finished blades, which eventually could be transformed into tools. At Sant-Michel-du-Touch, Toulouse (Torchy 2013), they were employed to saw wood, as they were sturdier than locally available Bedoulian chert blades. In other French sites all the recovered Monegros chert blades had been actually employed, which shows that they were a valuable item in terms of functional interest. Other examples of long blades supposedly made on Monegros chert are those found at Can Sadurní (Edo et al. 2012), in Catalonia, or Pinot 2, not far from Toulouse (Pons et al. 2015). Vaquer (2012), from a strictly de visu perspective, expresses the possibility that many of the Neolithic and Chalcolithic long blades from SE France and Catalonia had been made on Monegros chert, but he concludes that this is not the case: Catalonian blades were closer technically to the 
Provence elements, which were knapped in Forcalquier chert. This French variety seems to be similar to the Monegros type, after Vaquer, especially due to the presence of ribbons, although in the Iberian chert the ribbons are very narrow and sinuous.

In this same volume we present an on-going research related to the management of Monegros and local cherts in the Arba de Biel Basin (García-Simón et al. 2016). There, Monegros chert was commonly employed, although in variable proportions, throughout all the human occupations, especially for the retouched assemblage. The Ebro Evaporitic chert, already present in small quantities during the precedent millennia, is by far the most frequent raw material in Neolithic times, in connection with the incorporation of the aforesaid new retouch techniques.

Finally, we must recall the importance of the tabular cherts from the outcrops of Monte Oscuro: Despite being small sized, their knapping suitability is excellent and they were profusely employed for making sickle elements. We can quote the apparition of these peculiar chert tools in many sites of the Middle Ebro Basin: Carrasca de Almazorre (Figure 5d), Encantados de Belchite (Barandiarán 1971), La Mora de Somaén (Barandiarán 1975), Moro de Olvena (Utrilla 1995). They are also very common in surface assemblages: North of Monegros (Rey 1987), Hoya de Huesca (Montes \& Domingo 2014) or the prolific ensembles of Undués Pintano and Cortado de Baselga (Cava 1986; Maluquer de Motes 1957; Utrilla 1975). All of them belong to Chalcolithic and Bronze Age occupations, where this particular piece became very common in the toolkits.

As seen, there is still a lot of work to do in this particular research field. The forthcoming PhD dissertation by one of us (LMGS) will try to add light to this interesting topic, establishing the geological features of the main varieties and offering examples of their Prehistoric exploitation and management across the Basin.

\section{Acknowledgements}

This work has been partially benefited by a Research Grant from the Instituto de Estudios Altoaragoneses (2013 call). Currently L.M. García-Simón is a Junior Advanced ResearcherN3 at the University of Zaragoza, hired thanks to the Additional Funding of the Ramón y Cajal programme (ref. 2013-12613, Spanish Ministry of Economy and Competitiveness). R. Domingo is a Ramón y Cajal Research Fellow (ref. 2013-12613). The Research Project "Transiciones climáticas y adaptaciones sociales en la Prehistoria del Valle del Ebro" (HAR 2014-59042-P) helped us with additional funding. This work is part of the research lines of the Research Group "First Dwellers of the Ebro Basin” (H07) and the Universitary Institute of Environmental Sciences (IUCA).

\section{References}

Barandiarán, I. 1971, Cueva de los Encantados (Belchite, Zaragoza). Noticiario Arqueológico Hispánico, 16: 11-52. (in Spanish) (“Encantados Cave (Belchite, Zaragoza)”)

Barandiarán, I. 1974, Un taller de piedras de fusil en el Ebro medio. Cuadernos de etnología y etnografía de Navarra, 17: 189-228. (in Spanish) ("A gunflint workshop in the Middle Ebro”)

Barandiarán, I. 1975, Revisión estratigráfica de la cueva de la Mora (Somaén, Soria) 1968. Noticiario Arqueológico Hispánico, Prehistoria, 3: 11-85. (in Spanish) (“Stratigraphic review of the Mora Cave (Somaén, Soria)”) 
Cava, A. 1986, La industria lítica de la prehistoria reciente en la Cuenca del Ebro. Boletín del Museo de Zaragoza, 5: 5-72. (in Spanish) ("Lithic industry of the recent prehistory in the Ebro Basin”)

Dunham, R. J. 1962, Classification of carbonate rocks according to depositional texture. In: Classification of carbonate rocks (Ham, W.E., Ed.), American Association of Petroleum Geologists Memoir Vol. 1, American Association of Petroleum Geologists, Tulsa: p. 108-121.

García-Simón, L.M., Domingo, R., \& Montes, L, 2016, The marine chert from Las Lezas (Biel, Zaragoza) and its prehistoric exploitation. Journal of Lithic Studies, 3(2): 375387. doi:10.2218/jls.v3i2.1419

ISKM 2015 (2015), 10th International Symposium on Knappable Materials. On the rocks. University of Barcelona, September 2015. URL: http://www.ub.edu/cherts-symp2015/

Langlais, M., \& Sanchhi, D. 2016, Note sur les matières premières siliceuses exploitées par les Magdaléniens de la Grotte Gazel (Aude, France). In: Notions de terriroire et de mobilité (Bressy, C., Burke, A., Chalard, P., \& Martin, H., Eds.), Études et Recherches Archéologiques de l’Université de Liège (ERAUL) Vol. 116, Université de Liège, Liège: p. 71-75. (in French) ("The siliceous raw materials exploited by Magdalenian people in Gazel Cave (Aude, France)”)

Leorza, R. 2013, Estudio de las materias primas líticas. In: El campamento mesolítico del Cabezo de la Cruz. La Muela, Zaragoza (J.M. Rodanés \& Picazo, J.V., Eds.), Monografías arqueológicas, Vol. 45, Universidad de Zaragoza, Zaragoza, pp. 43-74. (in Spanish) ("Study of the lithic raw materials")

Maluquer de Motes, J. 1957, Los talleres de sílex al aire libre del Alto Aragón. Excavaciones en Navarra, 5: 63-86. (in Spanish) ("The open-air chert knapping sites of the Alto Aragón”)

Mangado, X. 2005. La caracterización y el aprovisionamiento de los recursos abióticos en la Prehistoria de Cataluña: Las materias primas silíceas del Paleolítico Superior Final y el Epipaleolítico. BAR International Series 1420, Archaeopress, Oxford, 205 p. (in Spanish) ("The caracterization and gathering of the abiotic resources in the Catalonian Prehistory: The lithic raw materials from the Upper Palaeolithic and the Epipalaeolithic”)

Montes, L., \& Domingo, R. 2014, Hallazgos singulares del Neolítico y del Calcolítico-Bronce en la Hoya de Huesca. Saldvie, 13-14(2013-2014): 125-139. (in Spanish) ("Singular findings from the Neolithic and the Chalcolithic-Bronce in the Hoya de Huesca”)

Montes, L., Domingo, R., González-Sampériz, P., Sebastián, M., Aranbarri, J., Castaños, P., García-Simón, L.M., Alcolea, M., \& Laborda, R. 2016, Landscape, resources and people during the Mesolithic and Neolithic times in NE Iberia: The Arba de Biel Basin. Quaternary International, 403: 133-150. doi:10.1016/j.quaint.2015.05.041

Perrin, T., Bellot-Gurlet, L., \& Jédikian-Cap, G. 2006, Les productions laminaires du gisement chasséen de Saint-Michel-du-Touch (Toulouse, Haute-Garonne). Premières réflexions. In: La fin de l'Âge de Pierre en Europe du Sud (Vaquer, J., \& Briois, F., Eds.), Actes de la table ronde de l'EHESS, Carcassonne, 5 et 6 septembre 2003. Centre d'Anthropologie, l'École des Hautes Études en Sciences Sociales (EHESS), Toulouse: p. 85-103. (in French) ("The laminar productions of the Chassean site of Saint-Micheldu-Touch (Toulouse, Haute-Garonne). First reflections”) 
Pons, F., Bruxelles, L., Léa, V., Vaquer, J., Bevilacqua, R., Jarry, M., \& Martin, H. 2015, Le site de Pinot 2 à Blagnac (Haute-Garonne) et le début du Néolithique moyen dans le Sud-Ouest de la France. Bulletin Préhistorique du Sud-Ouest, 23: 39-100. (in French) ("The Pinot 2 site at Blagnac (Haute-Garonne) and the beginnings of the Middle Neolithic in SW France”)

Quirantes, J. 1978, Estudio sedimentológico y estratigráfico del Terciario continental de los Monegros. Institución "Fernando el Católico”, Zaragoza, 200 p. (in Spanish) ("Sedimentological and stratigraphic study of the continental Tertiary in Monegros”)

Rey, J. 1987, La población prehistórica del interfluvio Flumen-Alcandre. Bolskan, 4: 67-122. (in Spanish) (Prehistoric population of the Flumen-Alcanadre interfluve”)

Roy, M., Tarriño, A., Benito-Calvo, A., Mora, R., \& Martínez-Moreno, J. 2013, Aprovisionamiento de sílex en el Prepirineo oriental durante el Paleolítico superior antiguo: El nivel arqueológico 497C de Cova Gran (Santa Linya, Lleida). Trabajos de Prehistoria, 70(1): 7-27. (in Spanish) (Chert gathering in the eastern Pre-Pyrenees along the ancient Upper Palaeolithic: Archaeological level 497C of Cova Gran (Santa Linya, Lleida)")

Roy, M., Mora, R., Plasencia, J., Martínez-Moreno, J., \& Benito-Calvo, A. in press, Quartzite selection in fluvial Deposits: The N12 level of Roca dels Bous (Middle Palaeolithic, southeastern Pyrenees). Quaternary International. 12 p. doi:10.1016/j.quaint.2015.09.010

Tarriño, A. 2001, Procedencia de los sílex de la industria lítica del yacimiento de Aizpea (Arive, Navarra). In: Cazadores-recolectores en el Pirineo Navarro. El sitio de Aizpea entre 8000 y 6000 años antes de ahora (Cava Almuzara, A., \& Barandiarán Maestu, I. Eds.), Anejos de Veleia Vol. 10, Universidad del País Vasco, Vitoria: p. 51-62. (in Spanish) ("Origin of the chert elements of the lithic industry from the site of Aizpea (Arive, Navarra)”)

Tarriño, A. 2005, Fuentes de aprovisionamiento de los sílex del yacimiento arqueológico de Mendandia (Sáseta, Condado de Treviño). In: El campamento prehistórico de Mendandia: Ocupaciones mesolíticas y neolíticas entre el 8500 y el 6400 B.P. (Alday, A., Ed.), Arabako Foru Aldundia, Vitoria: p. 465-486. (in Spanish) (“Gathering sources of the cherts from the archaeological site of Mendandia (Sáseta, Condado de Treviño)”)

Tilo, M. A. 1991, Estudio de los yacimientos líticos de superficie localizados entre Fraga y Candasnos (Huesca). Bolskan, 7: 109-164. (in Spanish) ("Study of the open-air sites located between Fraga and Candasnos (Huesca)")

Torchy, L. 2013, De l'amont vers l'aval: Function et gestion des productions lithiques dans les réseaux d'échanges du Chasséen méridional. $\mathrm{PhD}$ thesis, Université de Toulouse II, Toulouse, 361 p. (in French) ("From upstream to downstream: Function and management of the lithic productions in the networks of the southern Chassean")

Utrilla, P. 1975, Nuevo yacimiento del Bronce Antiguo en Alcañiz: El Cortado de Baselga. Miscelánea Arqueológica que al profesor Antonio Beltrán Martínez dedican sus discípulos de la Facultad de Filosofía y Letras de Zaragoza en ocasión de sus bodas de plata con la cátedra. Universidad de Zaragoza, Zaragoza, p. 85-96. (in Spanish) ("New site from the Ancient Bronze in Alcañiz: El Cortado de Baselga”)

Utrilla, P. 1995, Materiales líticos. La cueva del Moro de Olvena (Huesca), Vol. 1. Bolskan, 12: 49-86. (in Spanish) (“Lithic materials. The Moro de Olvena cave (Huesca)”) 
Vaquer, J., \& Remicourt, M. 2006, Rythmes et modalités d'approvisionnement en silex blond bédoulien dans le chasséen du bassin de l'Aude: Le cas d'Auriac, Carcassonne (Aude). Documents d'Archéologie en Rhône-Alpes et en Auvergne, 34: 39-56. (in French) (Gathering modalities and rhythms of bédoulien blonde chert in the Chassean from the Aude Basin: The case of Auriac, Carcassonne (Aude)”)

Vaquer, J., \& Vergély, H. 2006, L’utilisation du silex en plaquette dans le Néolithique final et le Chalcolithique du sud Massif Central aux Pyrénées. In: La fin de l'Âge de Pierre en Europe du Sud. Archives d'Écologie Préhistorique (Vaquer, J., \& Briois, F., Eds.), Centre d'Anthropologie, Toulouse, p. 175-204 (in French) ("Platelet chert employment in the Late Neolithic and Chalcolithic from the southern Massif Central to the Pyrenees”) 